\title{
Trying to Understand Axonal Regeneration in the CNS of Fish
}

\author{
Claudia A. O. Stuermer, * Martin Bastmeyer, Matthias Bähr, \\ Gabriele Strobel, and Katja Paschke†
}

Faculty of Biology, University of Konstanz, D-7750 Konstanz, Germany

\begin{abstract}
SUMMARY
In contrast to the situation in mammals and birds, neurons in the central nervous system (CNS) of fish-such as the retinal ganglion cells - are capable of regenerating their axons and restoring vision. Special properties of the glial cells and the neurons of the fish visual pathway appear to contribute to the success of axonal regeneration. The fish oligodendrocytes lack the axon growth inhibiting molecules that interfere with axonal extension in mammals. Instead, fish optic nerve oligodendrocytes support-at least in vitro-axonal elongation of fish as well as that of rat retinal axons. Moreover, the fish retinal ganglion cells re-express upon injury a set of growth-
\end{abstract}

\section{INTRODUCTION}

There is a surprising difference between neurons in the central nervous system (CNS) of amniotic and anamniotic vertebrates: Upon injury, axons in the CNS of mammals will form a few abortive sprouts perhaps, but otherwise fail to regenerate long processes (review: Skene, 1989). This deficiency contrasts to the capacity of neurons in the CNS of fish which readily regrow their axons. After optic nerve transection in fish, the retinal ganglion cells re-extend their axons and reinnervate their targetcenter, the optic tectum, in the appropriate retinotopic order. The regenerating axons form the right synaptic connections and restore vision (review: Gaze, 1970). Regeneration of lesioned axons in mam- associated cell surface molecules and equip the regenerating axons throughout their path and up into their target, the tectum opticum with these molecules. This may indicate that the injured fish ganglion cells reactivate the cellular machinery necessary for axonal regrowth and pathfinding. Furthermore, the target itself provides positional marker molecules even in adult fish. These marker molecules are required to guide the regenerating axons back to their retinotopic home territory within the tectum.

Keywords: axonal regeneration, fish CNS, oligodendrocytes, optic nerve transection.

mals is possible in the peripheral nervous system. Peripheral nerves are surrounded by Schwann cells, while the major CNS glial cell types are oligodendrocytes and astrocytes.

During the past decade it has become evident that the failure of axonal regeneration in the adult mammalian central nervous system (CNS) can be attributed-at least in part-to the unfavorable properties of the glial cell environment surrounding the lesioned axons. Oligodendrocytes and myelin carry proteins on their surface that inhibit axon growth (Caroni and Schwab, 1988a), and reactive astrocytes forming the so-called glial scar also impede axonal elongation (Bovolenta, Wandosell, and Nieto-Sampedro, 1991). Experimental manipulations improving the environmental conditions, in fact, made possible the regeneration of at least a small number of axons. Replacement of the optic nerve by a peripheral nerve graft with Schwann cells allowed the growth of a fraction of the injured retinal axons (Benfey and Aguayo, 1982). Such grafts, unfortunately, did not prevent ganglion cell death by which the majority of the 
axotomized neurons are lost. In culture, rat retinal explants extended axons when offered Schwann cells or immature astrocytes as a substrate (Bähr and Bunge, 1989, 1990). Other approaches consisted in the neutralization of the oligodendrocyte/ CNS myelin-associated inhibitors by specific antibodies (Caroni and Schwab, 1988b) and in the elimination of the oligodendrocytes by $\mathrm{X}$-irradiation. Both lead to the regrowth of a few corticospinal axons into the rat spinal cord (Schnell and Schwab, 1990; Schwab and Schnell, 1991).

Despite such remarkable achievements in overcoming the environmental impediments, the success of axonal regeneration in the mammalian CNS is rather poor when compared to fish. In goldfish, more than $95 \%$ of all ganglion cells of the retina survive and regrow their axons (Meyer, Sakurai, and Schauwecker, 1985). Preliminary new data suggest that up to $80 \%$ of neurons in the fish mid- and hindbrain forming descending fiber tracts will regenerate axons and succeed in crossing the site of injury after a complete transection of the spinal cord (C. A. O. Stuermer, unpublished data).

How can we understand the unique reactions of fish CNS neurons to axotomy in light of the insights into factors that impair mammalian neuronal regeneration? This review sum marizes the outcome of more recent experiments that may provide a glimpse into this complex problem.

\section{THE GLIAL CELL ENVIRONMENT OF THE GOLDFISH OPTIC NERVE}

Since oligodendrocytes and CNS myelin interfere with axonal regeneration in the CNS of mammals the first questions were whether equivalent glial cells and their associated inhibitors would be present in fish. If so, then would fish retinal neurons perhaps be able to overcome the inhibitory influence of these glial cells and therefore reform long axons?

\section{Fish Axons Encountering Rat Oligodendrocytes}

In fact, earlier data indicated the absence of such inhibitors from the fish CNS myelin. Carbonetto and colleagues (Carbonetto, Evans, and Cochard, 1987 ) showed that rat dorsal root ganglion (DRG) would extend axons when offered thin cryostat sections of fish optic nerves as a substrate. These neurons, however, would not grow on sections of mammalian CNS nerves. Moreover, biochemical assays by which the mammalian myelin oligodendrocyte inhibitory proteins were enriched, failed to reveal the existence of such proteins in preparation from the fish CNS (Caroni and Schwab, 1988a).

The outcome of several more recent in vitro assays was consistent with this notion. In one of these assays we tested the interaction of regenerating fish retinal axons with oligodendrocytes. We first cocultured rat optic nerve oligodendrocytes with fish retinal explants (Bastmeyer, Beckmann, Schwab, and Stuermer, 1991). The contacts of the growing fish axons with the mammalian glial cells were monitored with time-lapse videomicroscopy. When the fish axons touched the mammalian oligodendrocytes, the growth cones collapsed and pulled back or the axon grew around the cells, but did not cross them [Fig. 1 (a,b)]. In the presence of the specific antibody that neutralizes the mammalian inhibitor (Caroni and Schwab, 1988b), however, fish axons did manage to grow over the mammalian oligodendrocytes. These results indicated that regenerating fish retinal axons are sensitive to the mammalian oligodendrocyte/myelin-associated inhibitory proteins. In fact, the fish axons reacted in a manner that was identical to the behavior of mammalian axons upon encounter with mammalian oligodendrocytes and CNS myelin (Fawcett, Rokos, and Bakst, 1989; Bandtlow, Zachleder, and Schwab, 1990). The next step in our analysis consisted in evaluating the reaction of growing axons with oligodendrocytes derived from the fish optic nerve. This required isolating these glial cells and identifying them in culture.

\section{Fish Axons Encountering Fish Oligodendrocyte-Like Cells}

The glial cells that were obtained from the regenerating fish optic nerve differed in several respects from the typical mammalian oligodendrocytes (Bastmeyer et al., 1991; Hoppe, Bastmeyer, von Blankenfeld, Kettenmann, and Stuermer, 1991). These fish cells divided in culture and formed within a few weeks a network-like carpet. The morphology of the cells was typically elongated with veil-like protrusions on both ends. These cells were identified immunohistochemically as oligodendrocytes-or as we decided to call them-oligodendrocyte-like cells. They express the myelin proteins IP1 and IP2 (recognized by the monoclonal antibody (Mab) 6D2, kindly provided by Gunnar Jeserich, Osnabrück, Germany) (Fig. 2), which are typical for fish but absent from mammalian oligodendrocytes and myelin (Jeserich and Rauen, 
a
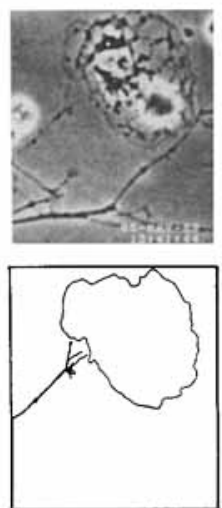

Rat Oligodendrocyte
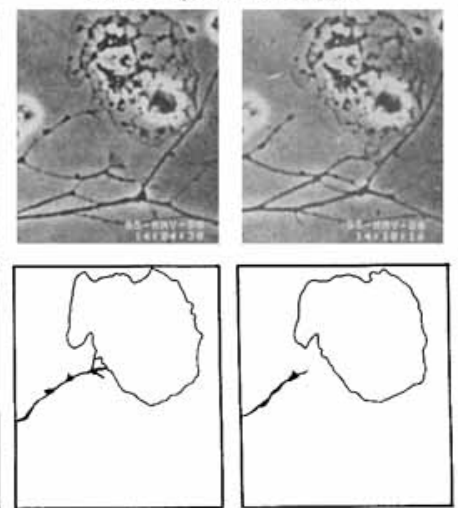

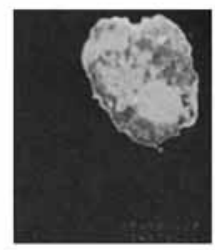

$\overline{80 \mathrm{um}}$

b

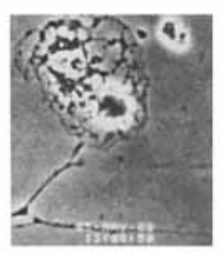

Rat Oligodendrocyte
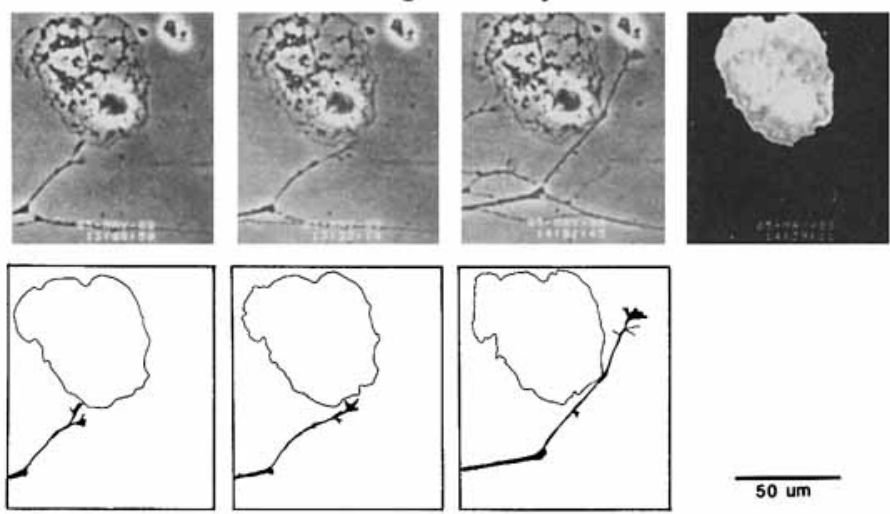

50 um

C
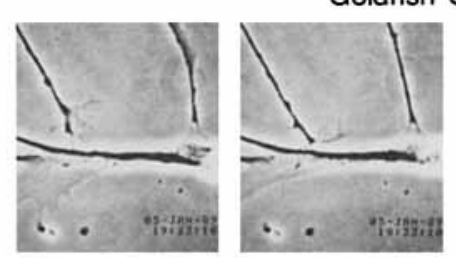

Goldfish Glial Cell
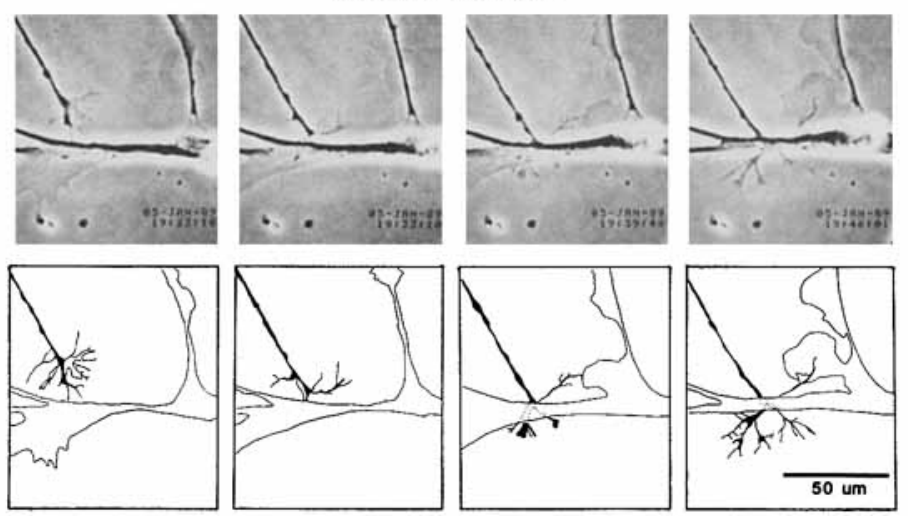

Figure 1 Selected frames from time-lapse video sequences and camera lucida tracings exemplifying the encounter of goldfish retinal growth cones with mammalian oligodendrocytes, and a goldfish optic nerve oligodendrocyte in vitro. The growth cones either grow around the cell (a) or collapse upon contact with a mammalian oligodendrocyte (b), but cross fish oligodendrocytes freely. (c) The mammalian oligodendrocyte was labeled with the antibody OI (fluorescence image) on the right hand. (From Development of the Visual System, D. M. K. Lam and C. Shatz, Eds., (C) 1991 MIT Press, reproduced with permission.) 


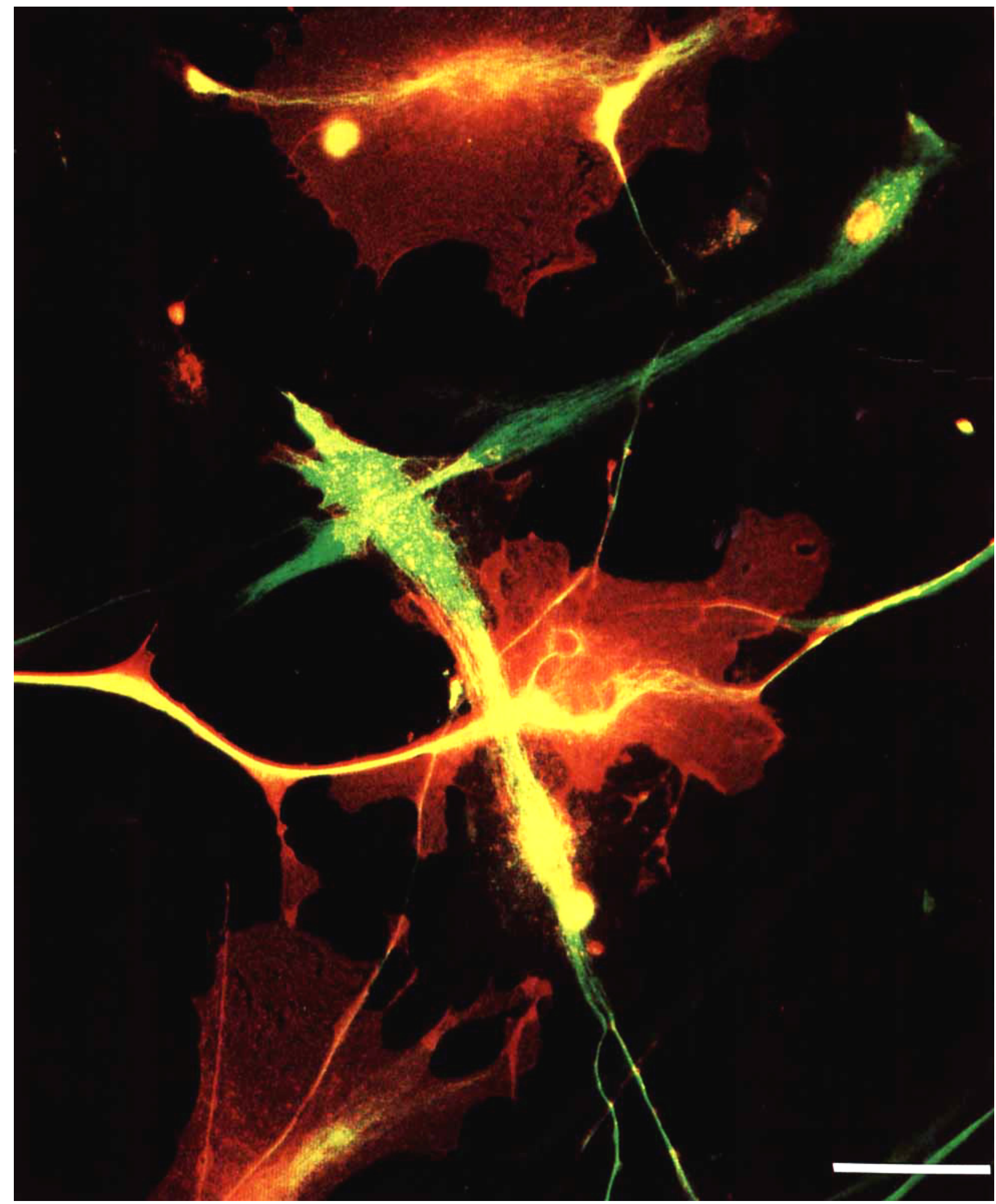

Figure 2 Goldfish optic nerve glial cells in a 10-day-old culture. The glial cells were double immunostained with Mab 6D2 (red) and polyclonal anti GFAP (green). Purely GFAP-positive glial cells (green) are astrocytes. The Mab 6D2-positive cells ( red ) represent fish oligodendrocyte-like cells. As typical for the oligodendrocyte-like cells in young cultures, they exhibit strands of GFAP-positive fibrils (here appearing yellow as a result of the red Mab 6D2 and green anti GFAP mixture). Scale bar $=50 \mu \mathrm{m}$. 
1990; Bastmeyer et al., 1991). At 1 week after explantation these oligodendrocyte-like cells also express the glial fibrillary acidic protein (GFAP) (recognized by a polyclonal antibody against fish GFAP, kindly provided by Samuel Nona, Manchester, England, UK) but to a much lesser extent than the astrocytes (Fig. 2). With time, however, the oligodendrocyte-like cells lose GFAP and increase their Mab 6D2 immunoreactivity (Bastmeyer et al., 1991). Moreover, in long-term cocultures of retinal axons and oligodendrocyte-like cells, these glial begin to enwrap the axons. Whether they even form a myelin sheath around the axons, is being investigated in ongoing experiments.

At present, what remains unclear is whether the oligodendrocyte-like cells of the fish optic nerve are the predecessors of mammalian oligodendrocytes or whether they represent another class of myelinating cells, as those from the mammalian olfactory bulb (Barnett and Noble, 1991). The evolution of myelinating glial cells is not yet understood to a degree that would allow a satisfying answer.

When fish retinal growth cones met these fish oligodendrocyte-like cells in a co-culture situation, the axons readily crossed these cells [Fig. $1(\mathrm{~b}, \mathrm{c})]$. Likewise, when exposed to fish CNS myelin preparations offered as a substrate to fish retinal explants, axons emerged and were capable of elongating on the myelin substrate. In a similar experiment performed with rat CNS myelin, however, outgrowth of axons from fish retinal explants failed (Bastmeyer et al., 1991).

All of the results are consistent with the notion that fish CNS myelin lacks the axon growth-inhibiting proteins of mammals, and that these inhibitors are absent from the oligodendrocyte-like cells derived from the regenerating fish optic nerve. In other words, one reason for the success of axonal regeneration in the fish optic nerve lies in the growth-permissive properties of the fish oligodendrocyte-like cells and the fish CNS myelin.

\section{Fish Retinal Growth Cones in vivo Are in Intimate Contact with Fish Optic Nerve Myelin}

To test whether this conclusion from in vitro studies would also apply to the in vivo situation, we searched to identify the elements with which the regenerating growth cones in the fish optic nerve are associated (Strobel and Stuermer, 1991). The growth cones of the regenerating axons were la- beled with horseradish peroxidase (HRP) from the eye. From ultrathin serial sections, the growth cones as well as the elements with which they were in intimate contact were reconstructed. Regenerating growth cones were found in direct membrane to membrane association with myelin debris (Strobel and Stuermer, 1991), a situation that would not be encountered in the mammalian CNS. They also were in close contact with a type of glial cell which by ultrastructural criteria from the literature on mammalian glial cells and according to Scholes on fish (Dowding, Maggs, and Scholes, 1991) either represented an oligodendrocyte precursor or a microglial cell. Surprisingly, the regenerating growth cones were not associated with astrocytes or the basal lamina surrounding the fascicles of the fish nerve. The latter elements were shown to represent the favored substrates for fish growth cones of the newly added ganglion cells (Easter, Bratton, and Scherer, 1984). Ongoing studies are devoted to further characterize the glial cells which regenerating fish retinal growth cones in vivo use as their substrate. To this point our observations support the idea that myelin/oligodendrocyte-associated inhibitory molecules that would repel or negatively affect the regrowing fish retinal axons are absent from the goldfish optic nerve in vivo.

\section{Fish Oligodendrocyte-Like Cells Support Axonal Regeneration}

A set of further experiments exceeded this conclusion: fish optic-nerve-derived oligodendrocyte-like cells are not only not inhibitory but are instead extremely growth supportive. Evidences fostering this view were, first, that the number of axons emerging from fish retinal explants on a substrate of fish oligodendrocyte-like cells was higher than on any other substrate used so far (Vielmetter, Stolze, Bonhoeffer, and Stuermer, 1990). Moreover, when retinal explants were placed on untreated plastic coverslips they failed to extend axons (Fig. 3). In the presence of fish oligodendrocyte-like cells, however, a substantial number of axons did emerge from the retinal explant (Fig. 3). (C. A. O. Stuermer, unpublished observations), suggesting that these glial cells indeed promote axonal growth (Bastmeyer, Bähr, and Stuermer, 1991; review: Stuermer, 1991a). Furthermore, the retinal growth cones appeared to preferentially grow in close contact with the oligodendrocyte-like cells, rendering the impression that these glial cells carry surface-associated molecules that are recog- 

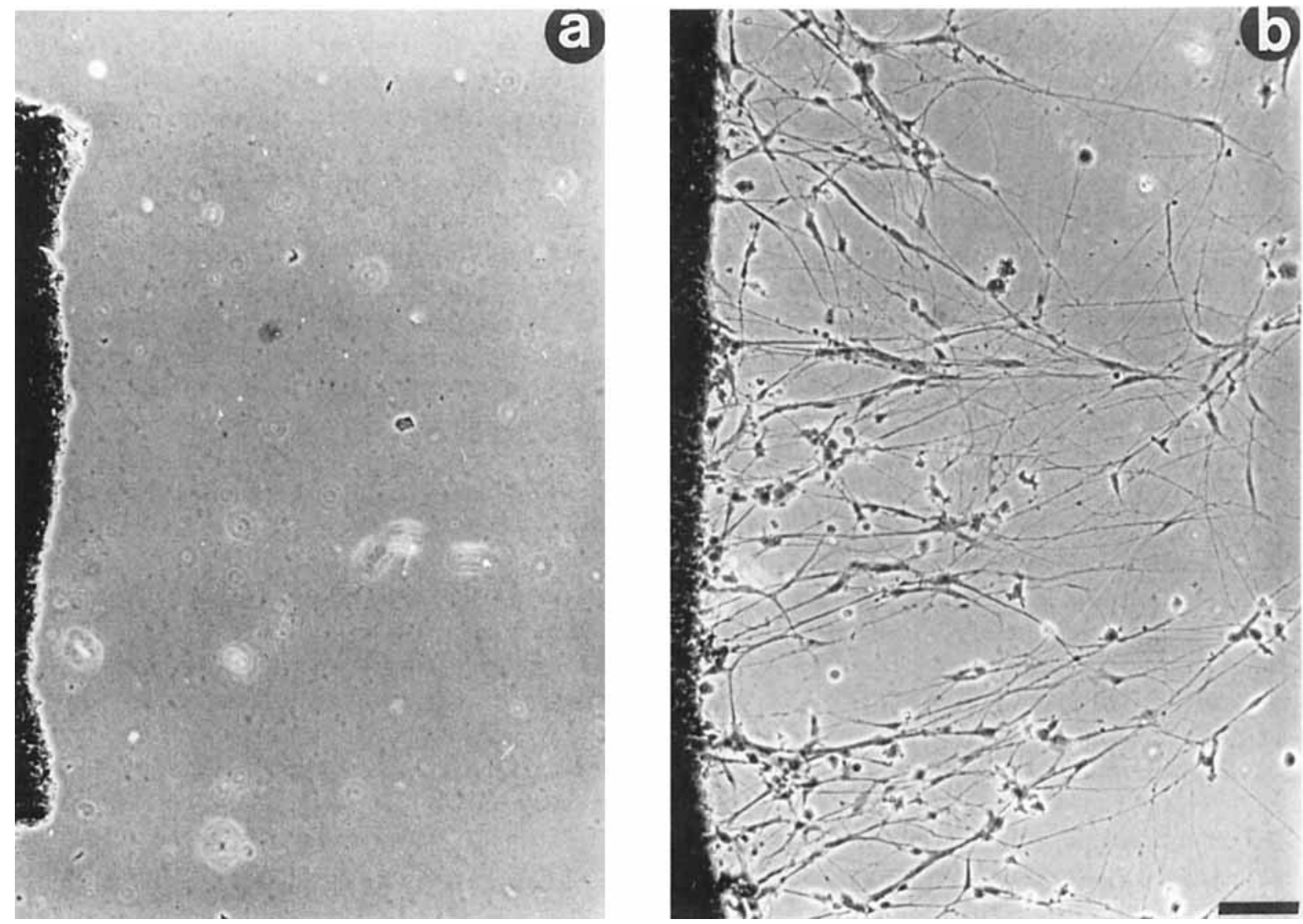

Figure 3 Axon outgrowth is stimulated by fish oligodendrocyte-like cells. (a) When segments of the fish retina are explanted on uncoated plastic coverslips, the retinal ganglion cells fail to emit axons. However, when they are explanted onto coverslips carrying fish oligodendrocytelike cells (b), a substantial number of retinal axons regenerate from the explant. The axons grow on the cells but also in areas where the oligodendrocyte-like cells had been and from where they had migrated away. Scale bar $=200 \mu \mathrm{m}$.

nized by the growth cones as favorable substrates for their elongation. Some axons also grew in areas where the oligodendrocyte-like cells had been but from where they had migrated away, giving the impression that the glial cells may leave some growthpromoting molecules on the coverslip like a snail trail.

These observations stimulated another crossspecies experiment with the following speculation. Since the inhibitory proteins of the mammalian oligodendrocytes negatively affected the fish retinal axons, would the growth-supportive properties on the surface of the fish oligodendrocyte-like cell exert a positive influence on injured rat retinal axons? In collaboration with Matthias Bähr ( MaxPlanck-Institute and University Hospital for Neurology, Tübingen, Germany), segments from the adult rat retina were explanted onto the network- like carpet of fish oligodendrocyte-like cells (Bastmeyer et al., 1991; review: Stuermer, 1991a). These co-cultures required conditions that were a compromise between the needs of a warm- and coldblooded vertebrate, as for instance, a temperature of $28^{\circ} \mathrm{C}$ and without an additional $\mathrm{O}_{2} / \mathrm{CO}_{2}$ supply commonly used for rat neural tissue. Adult rat retina explants usually fail to regenerate axons under such conditions. Yet, in the presence of the fish oligodendrocyte-like cells, a large number of axons emerged from the rat retinae, and these axons reached considerable length of up to 4-5 $\mathrm{mm}$. These rat axons grew in close contact with the surfaces of the fish oligodendrocyte-like cells and avoided fish oligodendrocyte-like cell-free regions.

Thus fish oligodendrocyte-like cells apparently possess cell surface-associated molecules that stimulate axonal regeneration. These molecules not 
only promote axonal regeneration of fish retinae but also that of adult rat retinae.

\section{FISH OLIGODENDROCYTE-LIKE CELLS EXPRESS AN L1-LIKE MOLECULE, THE E 587 ANTIGEN}

The finding that fish oligodendrocyte-like cells promote axonal growth in vitro, prompted the search for the cell surface-associated molecules that exert a growth-stimulating effect on the retinal axons. A widely used tool to detect such molecules is the creation and use of specific antibodies. Since the vast majority of existing antibodies against glia cell-associated cell surface molecules were raised against mammalian or avian cells and since such antibodies generally do not cross-react with fish, our knowledge on the molecular composition of the oligodendrocyte-like cell surface is very limited. However, we recently raised goldfish-specific monoclonal antibodies. One of these, Mab E 587, recognizes the fish oligodendrocyte-like cells. E 587 is directed against a $200-\mathrm{kD}$ glycoprotein, most likely belonging to the class of the $\mathrm{L} 1$ family of cell adhesion molecules (Vielmetter, Lottspeich, and Stuermer, 1991). While usually distributed evenly on the surface of the oligodendrocyte-like cells, this protein appears to cluster when processes of two cells overlap (Bastmeyer, Vielmetter, Jeserich, and Stuermer, 1990). The E 587 antigen is also found on the fish-regenerating retinal axons (Vielmetter et al., 1991) [Fig. 4(a)], an interesting aspect that will be considered more closely below. When the regenerating axons grow along the surface of the oligodendrocyte-like cells, the area of contact between the axon and the cell again exhibits a striking contact-dependent accumulation of the antigen [Fig. 4(b)] (Bastmeyer, Vielmetter, Jeserich, and Stuermer, 1990).

This contact-dependent clustering of the E 587 antigen during the growth of the fish retinal axons along the surface of the oligodendrocyte-like cells points to a role of this protein in the interaction of the axons and the glial cells. The gene encoding for this protein has yet to be cloned and the function of this protein to be more closely analyzed. However, the similarities between the $N$-terminal amino acid sequence of the E 587 antigen with that of the members of the L1-family (Vielmetter et al., 1991) suggests a function of this protein, as described for L1 family members in cell adhesion and in the promotion of axon growth (Rathjen, Wolf, Frank,
Bonhoeffer, and Rutishauser, 1987; Chang, Rathjen, and Raper, 1990, Lagenaur and Lemmon, 1989).

\section{THE RESPONSE OF THE FISH RETINAL GANGLION CELLS TO OPTIC NERVE SECTION: REGENERATING FISH RETINAL AXONS RE-EXPRESS GROWTH-ASSOCIATED CELL SURFACE PROTEINS}

In order to regenerate successfully, a neuron whose axon has been cut has to re-induce the relevant intracellular mechanisms and synthesize the necessary proteins to support axonal growth. Moreover, the long-range pathfinding functions that operate during development have to be reactivated as well as the conditions required for the reestablishment of the appropriate connections in the target. At the molecular level, these functions are only beginning to be elucidated. The success of retinal axon regeneration and the restoration of vision in fish implies that the fish ganglion cells and their targets possess the required features.

Earlier studies have demonstrated that fish retinal ganglion cells enlarge in size and increase their RNA and protein synthesis many times after optic nerve transection (McQuarrie and Grafstein, 1981 ). Among the proteins that are elevated in response to injury, a few were identified, such as the growth-associated protein Gap 43 (review Skene, 1991), cytoskeletal proteins, and proteins needed for the addition of new membranes (Perry, Burmeister, and Grafstein, 1985, 1987; Benowitz, Shashoua, and Yoon, 1981; for review: Skene, 1989, 1991; Grafstein, 1991).

More recently, we have succeeded in identifying several cell surface-associated proteins that are reexpressed during fish retinal ganglion cell axonal regeneration and that may play a role for axonal pathfinding and target reinnervation (Bastmeyer, Schlosshauer, and Stuermer, 1990; Vielmetter et al., 1991; Wehner and Stuermer, 1989, Stuermer, 1991b; Paschke, Lottspeich, and Stuermer, 1992). These proteins were discovered by monoclonal antibodies and they were defined as growth-associated cell surface proteins since the Mabs always and only stained the axons that were in a state of growth. All retinal axons are growing in the goldfish embryo during the development of the retinotectal pathway. In the adult fish, these proteins were confined (as shown by staining with the anti- 

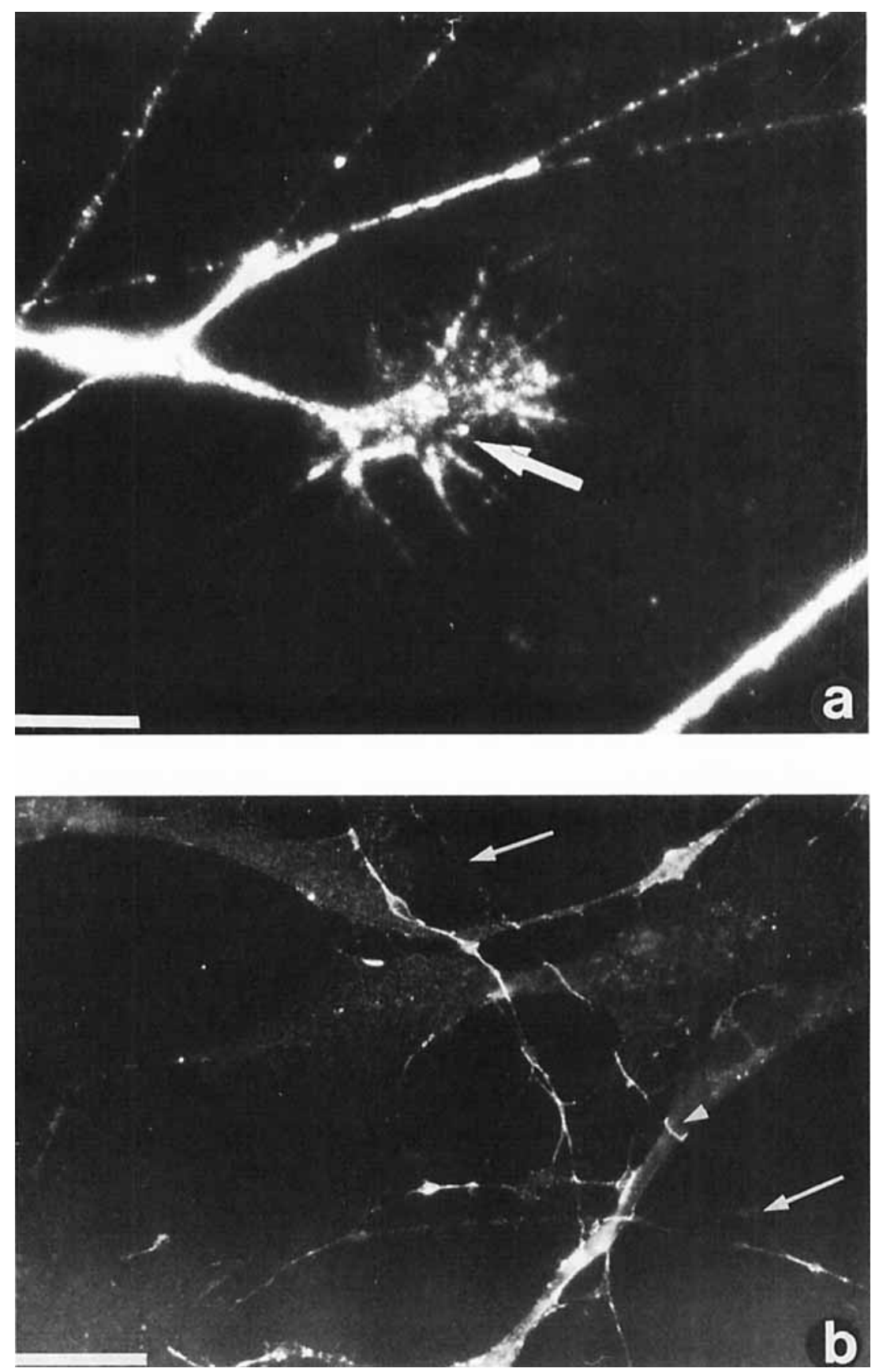

Figure 4 Contact-dependent clustering of the growth-associated cell surface molecule E 587 antigen. (a) Fish retinal axons regenerating in vitro on a laminin substrate carry the E 587 antigen homogeneously over their entire extent and into their growth cones (arrow). Immunostaining with Mab E 587. (From Vielmetter et al., Journal of Neuroscience, 11:3581-3593, (C) 1991 Society for Neuroscience, reproduced with permission.). Scale bar $=10 \mu \mathrm{m}$. (b) When fish retinal axons grow on the surface of fish oligodendrocyte-like cells, the E 587 antigen accumulates at contact sites between the axon and the cell. Where growing on the laminincoated glass coverslip, the axons exhibit hardly any Mab E 587 immunoreactivity (arrows) but are brightly stained where they grow on the oligodendrocyte-like cells (arrowhead) Scale bar $=100 \mu \mathrm{m}$. 
bodies) to the small group of growing axons that derive from the newborn ganglion cells at the retinal peripheral margin (Stuermer, 1991b) [Fig. $5(a, b)]$. In fish that grow throughout their life, precursor cells located at the retinal margin continuously produce new neurons (Johns, 1977) and the newly created ganglion cells send out their axons towards the optic tectum (Easter, Rusoff, and Kish, 1981). Only this small population of new axons were immunoreactive for the specific antibodies [Fig. 5(c)]. Growing axons must therefore possess an elevated concentration of these proteins identified by the Mabs. More mature axons-and these outnumber the new ones in any adult goldfish by far-had lost their Mab immunoreactivity [Fig. 5(c)]. The ganglion cells obviously reduce the production of the proteins and their insertion into the axonal membranes when the axonal connections between the retina and the tectum have matured. Upon optic nerve transection and during axonal regrowth, however, all regenerating retinal axons reexpress these proteins on their surfaces in the retina, in the optic nerve [Fig. 5(c)] and tract, and into the retinorecipient layers of the tectum [Fig. 5(d,e)]. The elevated level-again judged from the immunostaining pattern-remained high for several weeks or months but eventually declined to normal levels (Bastmeyer et al., 1990; Vielmetter et al., 1991; Wehner and Stuermer, 1989, Paschke, Lottspeich, and Stuermer, 1992). A major conclusion can be inferred from these observations: retinal ganglion cells in fish retain their ability to up-regulate the expression of growth-associated cell surface proteins into adulthood. Reexpression is induced when the axons are severed and when they regenerate. Furthermore, the ganglion cells are capable of down-regulating the expression of these proteins once appropriate connections with the target have been reformed.

The biochemical and molecular characterization of these proteins has not yet been completed, but ideas on their structure and function can be deduced from data obtained so far and from comparisons with known molecules. The first protein undergoing such a lesion-induced up-regulation was discovered by the monoclonal antibody D3 against neuronal (N) NCAM 180 (Schlosshauer, 1989; Bastmeyer et al., 1990). This was a surprising finding since NCAM 180 had previously not been reported to be regulated by neurons in such a dynamic fashion. The second spatially and temporally regulated protein is the $\mathrm{E} 587$ antigen, that was introduced in the preceeding paragraph as an L1-like molecule (Vielmetter et al., 1991; Bast- meyer et al., 1990). The third protein, "Neurolin," is an 84-kD glycoprotein (Paschke, Lottspeich, and Stuermer, 1992) that has homologies in its amino acid sequences to the recently discovered, novel cell adhesion molecule DM-Grasp (Burns et al., 1991 ) and SC-1 (Tanaka et al., 1991) in chick. The fourth growth-associated cell surface protein of $48 \mathrm{kD}$, the Reggie-antigen (Wehner and Stuermer, 1989), still awaits its further biochemical characterization.

Thus, according to our preliminary analyses three of the four growth-associated cell surface proteins do (NCAM 180) or most likely (E 587 antigen and Neurolin) belong to the class of cell adhesion molecules of the immunoglobulin ( $\mathrm{Ig}$ ) superfamily. From work in other species, the cell adhesion molecules of the $\mathrm{Ig}$ superfamily are known to subserve several functions during axon growth (review: Jessell, 1988). They are involved in the interaction of axons with cellular surfaces in their environment, mediate the fasciculation of axons with specific sets of other axons, and thus participate in axonal guidance, and some, such as L1 or G4 (the chick homolog of L1), (Rathjen et al., 1987) promote axonal growth (Chang et al., 1990; Lagenaur and Lemmon, 1987).

Our finding that a set of such growth-related cell surface and candidate cell adhesion molecules is reexpressed in fish during axonal regeneration indicates that the fish ganglion cells not only produce material for the formation of new processes but also equip the regenerating axons with the molecules required for axonal pathfinding and specific axon-environment interactions.

These molecules presented here are probably a few out of the many that may be reexpressed during retinal axonal regeneration and pathfinding in the fish visual system. We would expect that receptors for the interaction with extracellular matrix proteins, such as the integrins and molecules, involved in axon target recognition and synapse formation would be subjected to a similar lesion and regeneration-dependent regulation.

\section{CONTINUOUS EXPRESSION OF AXON- GUIDING COMPONENTS IN THE TARGET AND THE RESTORATION OF A RETINOTOPIC MAP BY REGENERATING FISH RETINAL AXONS}

Implicit in these considerations is the speculation that the environment of the regenerating axons, the optic nerve and tract, and the optic tectum, 

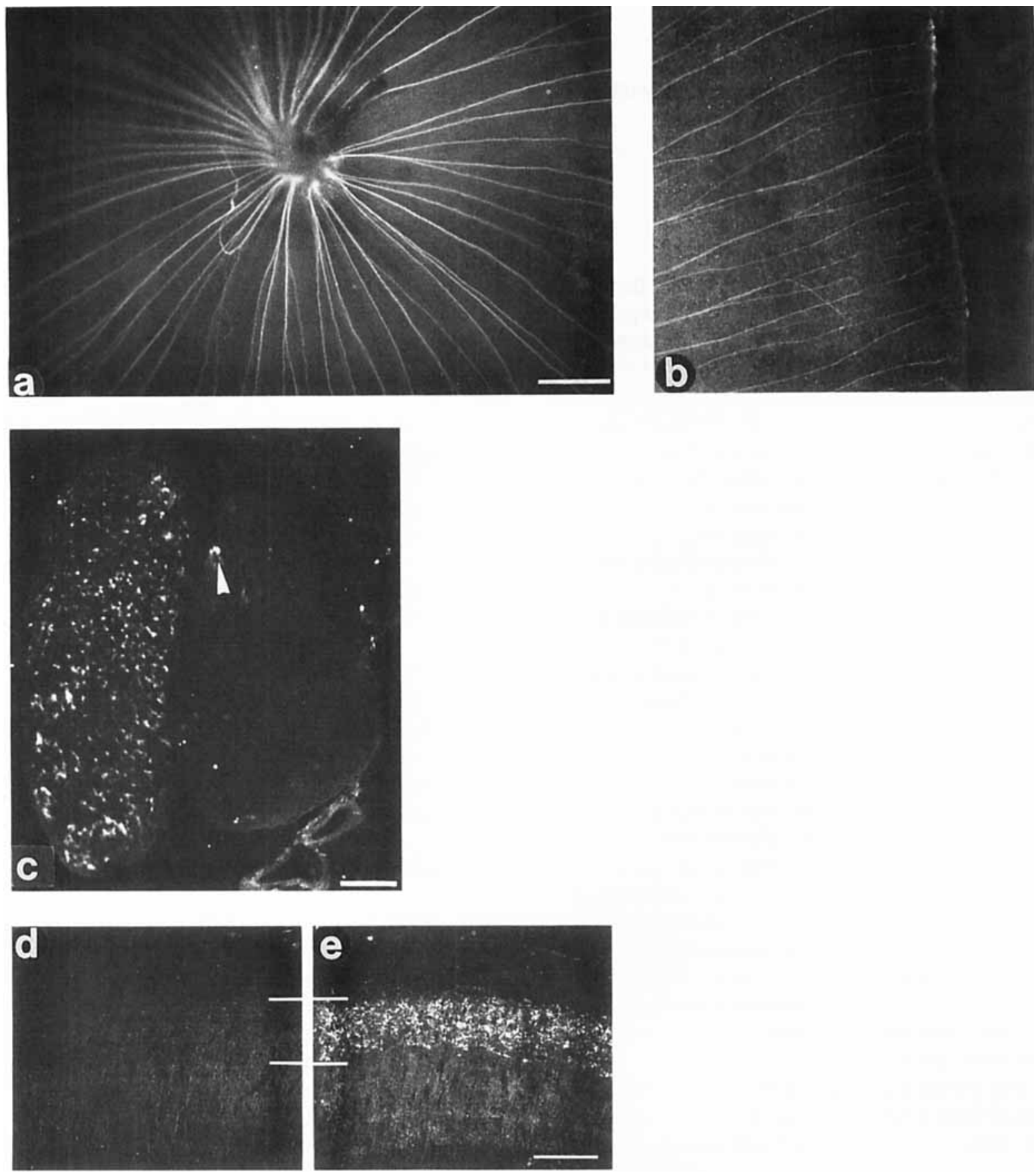

Figure 5 Growth-associated cell surface molecules are reexpressed during retinal axonal regeneration. (a) In any retina of normal adult goldfish, the growth-associated cell surface molecules are selectively associated with the small fascicles of new retinal axons exemplified by immunostaining with Mab E 587. (b) These axons take their origin from recently born ganglion cells at the retinal peripheral margin. Scale bar $=100 \mu \mathrm{m}$. (c) In the normal optic nerve, the new retinal axons cluster at one edge of the nerve forming a distinct bundle (arrowhead). Only these new axons carry the growth-associated cell surface molecules (here exemplified by immunostaining with Mab E 587). Older and more mature axons do not exhibit any staining suggesting that the older ganglion cells have down-regulated the expression of the antigens. In the optic nerve that had been sectioned 3 weeks earlier, however, many (and later all) regenerating retinal axons carry the antigens on their surfaces suggesting that the ganglion cells reexpress the growth-associated cell surface molecules during axonal regeneration. Scale bar $=100$ 
provides axon growth-supporting molecules as well as cues for axonal guidance and target recognition. We have presented a series of experiments showing that the fish optic nerve is permissive for axon growth, and that fish oligodendrocyte-like cells in vitro stimulate axonal regeneration. Whether these cells contribute to axonal regeneration in vivo remains to be tested. Other molecular components of the fish optic nerve and tract that may promote growth and guide axons remain to be discovered. Laminin may be one of them as suggested by Hopkins, Ford-Holevinski, McCoy, and Agranoff (1985).

In the target--the optic tectum-the invading axons require an additional set of landmarks, the "positional markers," to find their retinotopic home territory. That the fish tectum does provide positional markers for the invading axons is implicit in the outcome of the many studies that have demonstrated the reformation of a retinotopically well-organized projection by the retinal axons (for review: Gaze, 1970; Meyer et al., 1985; Schmidt, Turcotte, Buzzard, and Tieman, 1988; Stuermer, 1988a,b; Busse and Stuermer, 1989).

There is evidence that at least one specific molecule that is involved in axonal guidance and target recognition is expressed in the tectum opticum of fish. This molecule, however, appears to be constitutively expressed rather than regulated in response to lesioning of the optic nerve. This molecule, the "repellent guiding component" identified by $F$. Bonhoeffer and his colleagues in the caudal tectum of the embryonic chick (Walter et al., $1987 a, b)$ was found to also exist in the tectum of the fish (Vielmetter and Stuermer, 1989; Vielmetter, Walter and Stuermer, 1991) and to influence in fish as in chick (Walter et al., 1987a,b) the temporal retinal axons. While chick obviously reduce the concentration of this molecule such that caudal tectal membranes have lost the repellent guiding function when isolated from chick older than E16 (Walter et al., 1987a,b), such a decline was not noted in fish. In fact, the assays with fish retinal axons were performed with membranes isolated from normal adult fish tecta. These adult tectal membranes had retained, according to the out- come of these experiments their caudal tectal repellent component (Vielmetter and Stuermer, 1989).

One may speculate that the restoration of the retinotopic map of the regenerating retinal axons in the fish retinotectal system is possible because the fish tectum continues to provide the relevant tectal guidance components in adults. This thought can be extended to the retinotectal projection in chick or to the connection of the retinal axons with their target centers in the mammalian brain. One may not necessarily expect the reformation of a retinotopic order of axon terminals when avian or mammalian retinal axons are encouraged to regenerate into their target centers in adults, because the relevant guidance cues could be lost. On the other hand, the production of relevant guidance molecules could perhaps be reinduced by regenerating axons entering into the target centers. It has been demonstrated that retinal axons in mammals that were lead into the superior colliculus (the equivalent to the tectum opticum in lower vertebrates) by a peripheral nerve graft, can form synapses. These synapses are morphologically normal and functionally active (Keirstead et al., 1989; Carter, Bray, and Aguayo, 1989; reviewed in Bray et al., 1992), such that transmission of light-induced impulses from the retina onto the target neurons has been achieved. Normal vision, however, requires the restoration of the appropriate retinal terminal order in the target such as the retinotopic map, but the regenerating mammalian axon had not reinstalled retinotopia. Whether this means that the guidance molecules are indeed lacking in the adult mammalian colliculus, remains to be tested.

\section{PERSPECTIVES FOR SOME FUTURE EXPERIMENTS}

No doubt, our understanding of axonal regeneration is still very poor. Some new aspects for the explanation of the success of axonal regeneration in the fish retinotectal system has been achieved after all. This was possible, in particular, through the stimulating work that analyzed the reasons for

$\mu \mathrm{m}$. (d,e) In the tectum belonging to the normal optic nerve, the retinal axons are unlabeled (d). However, in the tectum connected to the previously sectioned optic nerve (e), all regenerating retinal axons in the retinorecipient layers SO and SFGS exhibit the antigens (here shown by immunostaining with Mab D3 against NCAM 180). Scale bar $=100 \mu \mathrm{m}$. (From Bastmeyer et al., Development, 108:299-311, (C) 1990, reproduced by permission.) Scale bar $=100 \mu \mathrm{m}$. 
the failure of spontaneous regeneration in the CNS of mammals and that circumvented environmental impediments for axon regrowth (Benfey and Aguayo, 1982; Schnell and Schwab, 1990). The findings in fish, on the other hand, gave rise to a number of ideas that could further elucidate the lesion-induced responses of mammalian CNS axons.

For instance, the new insights into the injury and regeneration-dependent reexpression of the three candidate cell adhesion molecules in the fish retinotectal pathway will be applied to further investigations on the lesion-induced responses of the rat retinal ganglion cells. Are rat ganglion cells capable of reinitiating an increased production of such molecules when their axons are severed? How would the expression of these cell surface molecules correlate to the expression of the intraaxonal protein Gap 43? A small proportion of ganglion cells express Gap 43 upon optic nerve transection in rats (Doster, Lozano, Aguayo, and Willard, 1991) and so do rat axons that regenerate in an experimentally altered and favorable environment.

It is conceivable that perhaps this small proportion of the neurons would also reexpress these cell surface molecules. Such experiments yield at solving whether there is a causal relation in the reexpression of these growth-associated cell surface molecules and axon regeneration. This aspect is not trivial and is of particular interest to us since it has been demonstrated that cell surface components with important functions in embryonic development are not necessarily reexpressed in later stages. This applies, for instance, to the cell adhesion and axon guidance molecule Tag 1, which is on spinal neurons and DRGs in mouse embryonic development (Dodd, Morton, Karagogeos, Yamamoto, and Jessell, 1988). However, only one group, the DRGs, reexpress Tag 1 in postembryonic stages when explanted in vitro, but the spinal neurons do not (Karagogeos, Morton, Casano, Dodd, and Jessell, 1991 ). During development, retinal ganglion cells of chick lose the ability to extend axons on a laminin substrate (Cohen, Burne, McKinlay, and Winter, 1987). This appears to result from a developmental loss of laminin receptors (Cohen, Nurcombe, Jeffrey, and Edgar, 1989). These examples suggest a rather complex developmental regulation of cell surface molecule expression in neurogenesis and during maturation. Before the expression and reexpression of the growth-associated cell surface molecules of the fish retinal axons can be studied in rats, the necessary tools, such as cross-reacting antibodies and DNA probes have to be created.

We would like to thank Marianne Wiechers and Ursula Topel for their excellent technical help during the experimental work. The work reviewed here was supported by the Deutsche Forschungsgemeinschaft, SFB 156, C6 to C.A.O.S., and the Hertie Stiftung.

\section{REFERENCES}

BÄHR, M. and Bunge, R. P. (1989). Functional status influences the ability of Schwann cells to support adult rat retinal ganglion cell survival and axonal regrowth. Exp. Neurot. 106:27-40.

BÄHR, M. and Bunge, R. P. (1990). Growth of adult rat retinal ganglion cell neurites on astrocytes. Glia 3:293-300.

Bandtlow, C., Zachleder, T., and Schwab, M. E. (1990). Oligodendrocytes arrest neurite growth by contact inhibition. J. Neurosci. 10:3837-3848.

BARNETT, S. C. and Noble, M. (1991). Identification of a novel glial cell isolated from the olfactory bulb by fluorescence activated cell sorting. Eur. J. Neurosci. Suppl. 4:102.

BASTMEYER, M., BÄHr, M., and StUermer, C. A. O. (1991). Growth of adult rat retinal axons on goldfish oligodendrocyte-like cells in vitro. Soc. Neurosci. Abstr. 17:211.

BASTMEYer, M., BeCKMANN, M., SCHWAB, M. E., and Stuermer, C. A. O. (1991). Growth of regenerating goldfish axons is inhibited by rat oligodendrocytes and CNS myelin but not by goldfish optic nerve tract oligodendrocytelike cells and fish CNS myelin. J. Neurosci. 11:626-640.

Bastmeyer, M., Schlosshauer, B., and Stuermer, C. A. O. (1990). The spatiotemporal distribution of $\mathrm{N}$-CAM in the retinotectal pathway of adult goldfish detected by the monoclonal antibody D3. Development 108:299-311.

BASTMEyer, M., Vielmetter, J., Jeserich, $G_{\text {., and }}$ Stuermer, C. A. O. (1990). Growth of retinal axons on goldfish optic nerve oligodendrocytes in vitro. Soc. Neurosci. Abstr. 16:1006.

Benfey, M. and Aguayo, A. J. (1981). Axonal elongation into peripheral nervous system "bridges" after central nervous system injury in adult rats. Science 214:93 I-933.

Benowitz, L. I., Shashoua, V. E., and Yoon, M. G. (1981). Specific changes in rapidly transported proteins during regeneration of the goldfish optic nerve. J. Neurosci. 1:300-307.

Bovolenta, P., WANDOSEll, F., and Nieto-SAMPEDRO, M. (1991). Central neurite outgrowth over glial scar tissue in vitro. In: The Nerve Growth Cone. P. C. Letourneau, S. B. Kater, E. R. Macagno, Eds., Raven Press, New York, pp. 477-488. 
Bray, G. M., Vidal-Sanz, M., Villegas-Perez, M. P., CARTfr, D. A., Zwimpfer, T., and Aguayo, A. Y. (1992). Growth and differentiation of regenerating CNS axons in adult mammals. In: The Nerve, Growth Cone, Letourneau, Kater, \& Macaguo, Eds., Raven Press, New York, pp. 489-504.

Burns, F. R., von KanNen, S., GUY, L., RaPer, J. A., KAMHOLZ, J., and ChANG, J. (1991). DM-Grasp, a novel immunoglobulin superfamily axonal surface protein that supports neurite extension. Neuron 7:209-220.

Busse, U. and Stuermer, C. A. O. (1989). Evidence for the stability of positional markers in the goldfish tectum. J. Comp. Neurol. 288:538-554.

Carbonetto, S., Evans, D., and Cochard, P. (1987). Nerve fiber growth in culture on tissue substrata from central and peripheral nervous systems. J. Neurosci. 7:610-620.

Caroni, P. and Schwab, M. E. (1988a). Two membrane protein fractions from rat central myelin with inhibitory properties for neurite growth and fibroblast spreading. J. Cell Biol. 106:1281-1288.

Caroni, P. and Schwab, M. E. (1988b). Antibody against myelin-associated inhibitor of neurite growth neutralizes nonpermissive substrate properties of $\mathrm{CNS}$ white matter. Neuron 1:85-96.

Carter, D., Bray, G. M., and Aguayo, A. Y. (1982). Regenerated retinal ganglion cell axons can form welldifferentiated synapses in the superior colliculus of adult hamsters. $J$. Neurosci. 9:4042-4050.

Chang, S., Rathjen, F. G., and Raper, J. A. (1990). Neurite outgrowth promoting activity of G4 and its inhibition by monoclonal antibodies. $J$. Neurosci. Res. 25:180-186.

Cohen, J., Burne, J. F., MCKinlay, C, and Winter, J. (1987). The role of laminin and the laminin/fibroectin receptor complex in the outgrowth of retinal ganglion cell axons. Devel. Biol. 122:407-418.

Cohen, J., Nurcombe, V., JefFrey, P., and Edgar, D. (1989). Developmental loss of functional laminin receptors on retinal ganglion cells is regulated by their target tissue, the optic tectum. Development 107:381387.

Dodd, J., Morton, S. B., Karagogeos, D., YamaMOTO, M., and JESSELL, T. M. (1988). Spatial regulation of axonal glycoprotein expression on subsets of embryonic spinal neurons. Neuron 1:105-116.

Doster, S. K., Lozano, A. M., Aguayo, A. J., and WILLARD, M. (1991). Expression of the growth-associated protein GPA-43 in adult retinal ganglion cells following axon injury. Neuron 6:1-13.

Dowding, A. J., MAGgs, A., and Scholes, J. (1991). Diversity amongst the microglia in growing and regenerating fish CNS: immunohistochemical characterization using Fl.1, and anti-macrophage monoclonal antibody. Glia 4:345-364.

Easter, S. S. JR., Bratton, B., and Scherer, S. S.
(1984). Growth-related order of the retinal fiber layer in goldfish. I. Neurosci. 4:2173-2190.

EAster, S. S. Jr., Rusoff, A. C., and Kish, P. E. (1981). The growth and organization of the optic nerve and tract in juvenile and adult goldfish. J. Neurosci. 1:793-811.

FAwCETT, J. W., Rokos, J., and BAKST, I. ( 1989 ). Oligodendrocytes repel axons and cause axonal growth cone collapse. J. Cell Sci. 92:93-100.

GAZE, R. M. (1970). The Formation of Nerve Connections. Academic Press, London.

GRAFSTEIN, B. (1991). The goldfish visual system as a model for the study of regeneration in the central nervous system. In: Development and Plasticity of the $\mathrm{Vi}$ sual System. J. R. Cronly-Dillon, Ed., MacMillan Press, London, pp. 190-205.

Hopkins, J. M., Ford-Holevinski, T. S., McCoy, J. P., and AGranofF, B. W. (1985). Laminin and optic nerve regeneration in the goldfish. $J$. Neurosci. 5:3030-3038.

Hoppe, D., Bastmeyer, M., von Blankenfeld, G., KettenmanN, H., and Stuermer, C. A. O. (1991). Two populations of glial cells from fish optic nerve/ tract with distinct electrophysiological properties. Exp. Brain Res. 87:383-388.

Jeserich, G. and Rauen, T. (1990). Cell cultures enriched in oligodendrocytes from the central nervous system of trout in terms of phenotypic expression exhibit parallels with cultured rat Schwann cells. Glia 3:65-74.

JESSELL, T. M. (1988). Adhesion molecules and the hierarchy of neural development. Neuron 1:3-13.

JoHNS, P. A. (1977). Growth of the adult goldfish eye. III. Source of the new retinal cells. J. Comp. Neurol. 176:343-357.

Karagogeos, D., Morton, S. B., Casano, F., Dodd, J., and JESSELL, T. J. (1991). Developmental expression of the axonal glycoprotein TAG-1: differential regulation by central and peripheral neurons in vitro. Development 112:51-67.

Keirstead, S. A., Rasminsky, M., Fukuda, Y., Carter, D. A., Aguayo, A. J., and Vidal-Sanz, M. (1989). Electrophysiologic responses in hamster superior colliculus evoked by regenerating retinal axons. Science 246:255-257.

Lagenaur, C. F. and Lemmon, V. (1987). An L1-like molecule, the 8D9 antigen, is a potent substrate for neurite extension. Proc. Natl. Acad. Sci. USA 84:7753-7757.

MCQuarrie, L. G. and GrafSTEIN, B. ( 1981 ). Effect of a conditioning lesion on optic nerve regeneration in goldfish. Brain Res, 216:253-264.

Meyer, R. L., Sakurai, K., and Schauwecker, E. (1985). Topography of regenerating optic fibers in goldfish traced with local wheat germ injections into retina: evidence for discontinuous microtopography in the retinotectal projection. J. Comp. Neurol. 239:27-43. 
PaschKe, K. A., LotTspeich, F., and Stuermer, C. A. O. (1992). Neurolin, a cell surface glycoprotein on growing retinal axons in the goldfish visual system is re-expressed during retinal axonal regeneration. $J$. Cell Biol. 117:863-875.

Perry, G. W., Burmeister, D. W., and Grafstejn, B. (1985). Changes in protein content of goldfish optic nerve during degeneration and regeneration following nerve crush. $J$. Neurochem. 44:1142-1151.

Perry, G. W., Burmeister, D. W., and Grafstein, B. (1987). Fast axonally transported proteins in regenerating goldfish optic axons. $J$. Neurosci. 7:792-806.

Rathjen, F. G., Wolf, J. M., Frank, R., Bonhoeffer, F., and Rutishauser, U. (1987). Membrane glycoproteins involved in neurite fasciculation. J. Cell Biol. 104:343-353.

SCHLOSSHAUER, B. ( 1989). Purification of neuronal cell surface proteins and generation for epitope-specific monoclonal antibodies against cell adhesion molecules. J. Neurochem. 52:82-92.

SChmidt, J. T., Turcotte, J. C., Buzzard, M., and TIEMAN, D. G. (1988). Staining of regenerated optic arbors in goldfish tectum. I. Comp. Neurol: 269:565591.

Schnell, L. and Schwab, M. E. (1990). Axonal regeneration in the rat spinal cord produced by an antibody against myelin-associated neurite growth inhibitors. Nature 343:269-272.

SCHWAB, M. E. and SCHNell, L. (1991). Channeling of developing rat corticospinal tract axons by myelin-associated neurite growth inhibitors. $J$. Neurosci. 11:709-721.

Skene, J. H. P. (1989). Axonal growth-associated proteins. Annu. Rev. Neurosci. 12:127-156.

SkENE, J. H. P. (1991). Retrograde pathways controlling expression of a major growth cone component in the adult CNS. In: The Nerve Growth Cone. P. C. Letourneau, S. B. Kater, E. R. Macagno, Eds., Raven Press. New York, pp. 463-475.

Strobel, G. and Stuermer, C. A. O. (1991). Substrates for regenerating goldfish retinal axons in vivo. Soc. Neurosci. Abstr. 17:211.

STUERMER, C. A. O. (1988a). Trajectories of regenerating retinal axons in the goldfish tectum: I. A comparison of normal and regenerated axons at late regeneration stages. J. Comp. Neurol. 267:55-68.

STUERMER, C. A. O. (1988b). Trajectories of regenerating retinal axons in the goldfish tectum: II. Explor- atory branches and growth cones on axons at early regeneration stages. J. Comp. Neurol. 267:69-91.

Stuermer, C. A. O. (1991a). Axon-glial cell interactions during optic nerve regeneration. Neurosci. Facts 2:1-4,

Stuermer, C. A. O. (1991b). Axonal pathfinding and target recognition of retinal axons in fish during development and regeneration. In: The Development of the Visual System. D. Lam, C. J. Shatz, Eds., MIT Press, Cambridge, MA, pp. 133-151.

Tanaka, H., Matsui, T., Agato, A., Tomura, M., Kubota, I., McFarland, K. C., KoHr, B., LeE, A., Phillips, H. S., and Shelton, D. L. ( 1991 ). Molecular cloning and expression of a novel adhesion molecule, SC1. Neuron 7:535-545.

VIELMETTER, J., LOTTSPEICH, F, and STUERMER, C. A. O. (1991). The monoclonal antibody E 587 recognizes growing (new and regenerating) retinal axons in the goldfish retinotectal pathway. J. Neurosci. 11:3581-3593.

Vielmetter, J. and Stuermer, C. A. O. (1989). Goldfish retinal axons respond to position-specific properties of tectal cell membranes in vitro. Neuron 2:13311339.

Vielmetter, J., Stolze, B., BonhoefFer, F., and STuERmer, C. A. O. (1990). In vitro assay to test differential substrate affinities of growing axons and migratory cells. Exp. Brain Res. 81:283-287.

Vielmetter, J., Walter, J., and Stuermer, C. A. O. (1991). Regenerating retinal axons of goldfish respond to a repellent guiding component on caudal tectal membranes of adult fish and embryonic chick. $J$. Comp. Neurol. 310:1-9.

Villegas-PÉrez, M. P., VIDAl-SANZ, M., Bray, G. M., and AGUAYO, A. J. (1988). Influences of peripheral nerve grafts on the survival and regrowth of axotomized retinal ganglion cells in adult rats. $J$. Neurosci. 8:265-280.

Walter, J., Henke-Fahle, S., and BonhoefFer, F. (1987a). Avoidance of posterior tectal membranes by temporal retinal axons. Development 101:909-913.

Walter, J., Kern-Veits, B., Huf, J., Stolze, B., and BONHOEFFER, F. (1987b). Recognition of positionspecific properties of tectal cell membranes by retinal axons in vitro. Development 101:685--696.

Wehner, K. and StUermer, C. A. O. (1989). Monoclonal antibody $M 802$ recognizes regenerating retinal axons in goldfish. Neturosci. Abstr. 15:1027. 